\title{
'In th'armor of a Pagan knight': Romance and Anachronism East of England in Book V of The Faerie Queene and Tamburlaine
}

Elizabethan England's relationship with the Muslim world poses special challenges for cultural history. Modern critical paradigms, concerned as they are with issues of empire and colonialism, often have difficulty conceptualizing an England whose imperial project had barely begun and whose 'colonial' discourse was, in Daniel Vitkus's words, 'merely the premature articulation of a third-rank power'. ${ }^{1}$ England's national achievements lagged far behind not only European rivals like Spain but also powerful Muslim empires like Ottoman Turkey, which challenged the power of all Europe. This combination of rising nationalism, extensive cross-cultural contact, and limited geopolitical and economic power created a public appetite for stories of heroic Englishmen and Christians who resisted the wealth and power of the foreign others they constructed. Popular pamphlets and intelligences told of Christian captives on the Barbary Coast who had bravely resisted conversion or pulled off daring escapes. In the theatre, as Nabil Matar has observed, playwrights 'took up the cudgel against the Muslims and appealed to a populace that felt threatened by, and confused at, the appearance of the Muslim Other in their metropolis, in their harbors, and across their Mediterranean and Atlantic trading routes. ${ }^{2}$

There was, however, another means of negotiating the tensions created by the Muslim other. Spenser, Marlowe in Tamburlaine, and other writers of the period explored the Islamic challenge by displacing it into the space of romance and classical literature, containing it in an imaginative realm drawn from their syncretic humanist educations and constructed out of elements drawn from a wide span of history and literature. Scholars going back to Samuel Chew have tended to see the public stage as the primary site for portraying the Muslim other, and literary historians like Nabil Matar and Daniel Vitkus have added popular pamphlets and official records to the body of work under study. ${ }^{3}$ Matar correctly points out that, unlike France, Spain, Portugal, and Italy, whose histories were shaped to a far greater extent by direct contact and conflict with the Muslim world, 'England did not produce an anti-Muslim national epic' like La Chanson de Roland, Gerusalemme Liberata, or Los Mocedades de Rodrigo, and that references to Muslims appear much less frequently in English epics like The Faerie Queene and Paradise Lost. ${ }^{4}$ This does not mean, however, that the figure of the Muslim was not present and important in the English romance of the time, as the recent work of Benedict 
Robinson demonstrates. ${ }^{5}$ Muslims were, as Vitkus argues, 'comprehended through residual history and contemporary cross-cultural encounters, not in terms of East-versus-West or colonizer-versus-colonized, but as a complex and unstable meeting ground for divergent cultural and religious groups, ${ }^{6}{ }^{6} \mathrm{a}$ variety that could not be adequately contained by appeals to classical or biblical antiquity. The very instability of this contact space enabled the sort of syncretic, figural engagement with the Islamic world that characterizes both English romance and the Elizabethan plays that drew on the romance tradition. In the romance space of The Faerie Queene the concept of the Turk is conflated with that of Herodotus's Persian conquerors, and the fearsome Souldan of Book V can represent both the Ottoman Sultan and Philip II.

This same syncretism allowed the English self, as figured in the romance, to incorporate elements of the other for its own purposes. As Vitkus observes, 'In their relations with cultural contestants like France, Spain, Portugal, Venice, and Turkey, the English were, in many ways, a society of mimic-men who were learning (or hoping) to imitate alien models of power, wealth, and luxury,, 7 and this aspirational mimicry can be seen in the romance spaces where contact with various others took place. This imitation and the forms of mimesis that accompanied it allow writers like Spenser to confront and contain rivals who could not be outdone in material terms but also serve to undercut the integrity of the very English identity they attempt to construct. In facing the Souldan in Book V, Artegall turns Turk, and Arthur defeats the tyrant in battle with a mirrored shield, destroying him through an act of mimesis. Anachronism and mimesis, making the Muslim other a figure in a transhistorical drama and appropriating aspects of his identity for one's own self-fashioning, were central to the construction of both the Turk and the Englishman in Elizabethan literature. This literary strategy reflects what Jonathan Burton has called 'the period's conditional suspension and activation of anti-Islamic prejudice, ${ }^{8}$ with the humbling of the sultan requiring the sort of cross-cultural mimesis and exchange that brings any unified English identity into question. This article will explore this dynamic in Book V of The Faerie Queene and Christopher Marlowe's Tamburlaine, with a glance at the historical hybrid hero Scanderbeg's role in the English literary imagination. The incorporation of Muslim figures into the romance space highlights the hopes and anxieties attending cross-cultural contact and the commensurability of human beings, and the double-sided capacity of the English to become like those with whom they trafficked. 


\section{The Souldan and the Mirror}

Since John Upton's 1758 edition of The Faerie Queene made the connection in its footnotes, the Souldan has been read as representing King Philip of Spain and his defeat as that of the Armada in 1588. Such a representation can no doubt be found in Spenser's densely layered allegory. The Souldan also draws on the long Protestant polemical tradition of conflating Catholic and Muslim foes. In Actes and Monuments, John Foxe considers, 'in comparing the Turk with the pope, if a question be asked, whether of them is the truer or greater Antichrist' and concedes that 'the Turke is the more open and manifest enemy against Christ and his Church' before declining to discern 'whether of them hath consumed and spilt more Christian bloud'. 'The martial figure of the Turkish sultan served as the more overt expression of a deeper evil that used both Islam and the Roman Catholic faith as its tools. The Souldan is thus several tyrants from the English imagination simultaneously, standing in for Persian Darius, Turkish Selimus, and Spanish Philip while prefiguring the antichrist. Spenser was no doubt familiar with the power of the Ottoman Empire and the other Muslim nations of the day, as well as the challenge they presented to Protestant piety. One of the seven Bead-men in The Faerie Queene's House of Holiness connects the fourth Work of Mercy, the visitation of prisoners, to the familiar figure of the European held for ransom in Barbary:

The fourth appointed to his office was,

Poore prisoners to relieue with gratious ayd,

And captives to redeeme with price of bras,

From Turkes and Sarazins, which them had stayd. $\quad\left(\right.$ I.x.40.1-4) ${ }^{10}$

More relevant for this study, in 1596 Spenser wrote a dedicatory sonnet for The Historie of George Castriot, surnamed Scanderbeg, King of Albanie, an English translation of a French history of the Albanian anti-Ottoman hero Gjergj Kastrioti (the Italian rendering Georgio Castriota was used in the West). Known as Scanderbeg, a derivative of his Turkish title Iskander Bey (Lord Alexander), Kastrioti was born around 1405, shortly after Timur's invasion had left the Ottoman Empire in disarray. His father Gjon Kastrioti was an Epirot lord who fought Sultan Murad II's invasion of what is now Albania. His resistance failed, and he was forced to submit to Ottoman rule and surrender his four sons to the Sultan as noble hostages. Some western chroniclers seized on this fact and portrayed Katrioti as the childhood playmate of the 
future sultan Mehmed II, even though the heir to the throne was twenty-eight years younger. Kastrioti converted to Islam in captivity and served twenty years as an Ottoman soldier in Anatolia and the Balkans, rising to the rank of general and earning the honorific title of Iskander Bey. In 1443 he, along with 300 Albanian soldiers, deserted during a battle with the Hungarians and took command of an Albanian castle via a forged letter from the Sultan. He then turned renegade, reconverting to Christianity and immediately launching a tenacious Albanian revolt that resisted the Ottomans for many years. Scanderbeg's military success eventually forced Mehmed II, the conqueror of Constantinople, to expediently sign a three year armistice and recognize him as lord of Albania and Epirus in 1461. Scanderbeg died in 1468, and Albania remained independent until a second Ottoman conquest in 1478. According to the Historie, the victorious Turkish troops plundered Scanderbeg's tomb and took pieces of his bones as talismans to bring them glory in battle. ${ }^{11}$ Pope Calixtus III called Scanderbeg 'an athlete of Christendom'. His European admirers credited him with delaying the 1453 fall of Constantinople, much as Timur did in 1402, and blocking an Ottoman invasion of Italy by tying up the Turkish army in the Albanian mountains. ${ }^{12}$

Scanderbeg's name became a shorthand term for martial prowess in Elizabethan England, ranked with Alexander and Caesar. Richard Hillman has argued that the tales of Scanderbeg's victories, and his contest with Mehmed the Conqueror, are reflected in Prince Hal's rivalry with Hotspur and triumph at Agincourt in Shakespeare's Henriad. ${ }^{13}$ The July 1601 Stationers' Register includes an entry for 'The true historye of George Scanderbeg as yt was lately played by the right honorable the Earle of Oxenforde his servants'. ${ }^{14}$ Sadly, no other trace of this play survives. In his dedication to the prose Historie, Spenser hails Scanderbeg as equal to the 'old Heroes' (3) of 'vaine antiquitie' (1):

Lo one, whom later age hath brought to light,

Matchable to the greatest of those great:

Great both by name, and great in power and might,

And meriting a mere triumphant seate.

The scourge of Turkes, and plague of infidels,

Thy acts, o Scanderbeg, this volume tels.

This Scanderbeg, a Christian-turned-Muslim-turned-Christian hero, bearing the name of Alexander the Great and, in Spenser's sonnet, equally worthy 
of the title, is an amalgam figure who in many ways parallels the syncretic identity adopted by Arthur and Artegall in their fight with the Souldan. Like Scanderbeg, the knights are Christian heroes built out of elements both Muslim and Christian, ancient and modern, who turn the Turk's own prowess back against him. Spenser's knights become heroes who both resist and appropriate Muslim and pagan alterity. ${ }^{16}$

In Book V canto viii, Artegall and Arthur are reunited when they rescue the damsel Samient from a pair of paynim knights. They readily slay their foes, only to turn on each other until Samient implores them to stop. She tells them of her mistress, the just queen Mercilla, and of the Souldan,

a mighty man, which wonnes here by

That with most fell despight and deadly hate,

Seekes to subuert her Crowne and dignity,

And all her power doth thereunto apply:

And her good Knights, of which so brave a band

Serues her, as any Princess under sky,

He either spoiles, if they against him stand,

Or to his part allures, and bribeth under hand.

(viii.18.2-9)

Like the Turkish and Moorish leaders in both pamphlet and drama, the Souldan exerts power over Christians through both force and the 'allures' of his wealth and prestige. While his individual knights can be defeated in direct combat, the heroes can only confront the Souldan 'by counterfet disguise' (viii.25.1), dressing Artegall 'in th'armor of a Pagan knight' (viii.26.2) and having him present Samient to the Souldan as a captive. Unlike the other tyrants who inhabit Book V, the Souldan needs to be drawn into the story by trickery. The knights' scheme draws him out onto the field and into the syncretic narrative that defines and confines him. Artegall, however briefly, turns Turk, with even the Souldan's wife Adicia thinking him 'her Paynim knight' (viii.26.7). By having him turn Turk, Spenser connects Artegall with a rich source of early modern England's identity anxiety.

Artegall's masquerade and presentation of the captive damsel provides a 'casus belli' for Arthur, who in 'A bold defyance' (viii.27.8) comes to the rescue. One could perhaps make an analogy between the presentation of Samient as a prisoner and the use of captives as bargaining chips and provocations in Mediterranean war and diplomacy, but I prefer to see this odd scheme as a synecdoche for the narrative move Spenser has to make to draw 
the Muslim other into his narrative, to make the Souldan a pagan villain. The Souldan is transformed into a tyrant out of the classical and biblical past, climbing into 'a charret hye, / With yron wheeles and hookes arm'd dreadfully' (viii.28.4-5). This bladed chariot has its antecedents in the scythed chariots driven by Darius's Persian army in Quintus Curtius's history of Alexander the Great, with 'scythes fixed in the rim of the wheels', and in the Selucid chariots 'armed with scythes' that appear in the Second Book of Maccebees. ${ }^{17}$ In another mythic addition, the chariot is pulled by the horses of Thracian Diomedes, 'fed / With flesh of men' (viii.28.6-7) and tamed in the ninth labour of Hercules.

The fight thus becomes one not between Christian and Muslim, a conflict in which the Christian side had seen little success, but one between Arthur, figured in contrast as both Alexander and Hercules, and the figure of a timespanning pagan tyrant. ${ }^{18}$ Nevertheless, Arthur is unable to land a blow on the Souldan - 'Yet could the Prince not nigh unto him goe, / That one sure stroke he might unto him reach' (viii.37.3-4). Instead, he wins through an act of mimesis. For the first time, Arthur deliberately unveils the 'glistering ray' (I.vii.34.5) of his diamond shield. As described in Book I, this shield has fearsome metamorphic powers:

Men into stones therewith he could transmew, And stones to dust, and dust to nought at all; And when him list the prouder lookes subdew He would them gazing blind, or turn to other hew. (vii.35.6-9)

'Like lightning flash' (V.viii.38.1), Arthur unveils his shield before the gaze of the fearsome horses and 'So did the sight thereof their sense dismay, / That back again upon themselues they turned' (viii.38.2-3). Faced with their own image, the terrified horses are translated from Diomedes's steeds to Phaethon's, causing the Souldan to lose control and perish in a spectacular crash. The sword cannot defeat the Turk, but narrative, the enclosing of the Turk in stories and history from the pre-Christian past, can reduce him a mere figure of the infidel tyrant and let his own great power destroy him.

This syncretic mimesis allows a weak and marginal England to define itself amid mighty empires past and present. This victory, however, carries with it a real risk. The appropriation of pagan arms, be they the Saracen armour worn by a counterfeiting Artegall or the aura of Alexander and Hercules around Arthur, threatens to undermine or subsume whatever is meant to be essential 
and distinct in the Christian English knight. Artegall's appropriation of pagan arms and identity evokes both the heroic intrigues of Scanderbeg and the opportunistic conversions of captured English sailors in Barbary, condemned in a 1627 sermon by Henry Byam as 'Musselmans in Turkie and Christians at home; doffing their religion as they do their clothes'. ${ }^{19}$ Imitation gives the underdog knights great power, but utterly entangles their identity with that of the other they face. This process bears an intriguing resemblance to the sort of liberating post-colonial mimesis described by Michael Taussig:

Mastery is no longer possible. The West as mirrored in the eyes and handiwork of its Others undermines the stability which mastery needs. What remains is unsettled and unsettling interpretation in constant movement with itself — what I have called a Nervous System - because the interpreting self is itself grafted into the object of study. The self enters into the alter against which the self is defined and sustained. ${ }^{20}$

Barbara Fuchs examines this mimetic appropriation of Muslim power as a component of early English imperialism, which she characterizes as a series of pointed acts of mimesis that can 'operate both as a weapon of the state, encouraged and promoted in the emulation of its rivals, and as a weapon against the same state, forced by imitators to relinquish its original preeminence. ${ }^{21}$ Arthur and Artegall's mimetic gambit can indeed be read as an early articulation of English imperialism, but this analysis is more concerned with the effect of this power on a sense of national identity than its utility to the state. The mastery of the Muslim other, as mirrored in the eyes and handiwork of Spenser, is undermined by an unsettled interpretation that spans space and time. A dizzying array of acquired traditions is assembled to construct a foe both fearsome and foredoomed and a hero both powerful and rootless. The Christian English self is built from the same materials as the infidel tyrant, calling into question the very distinctions they were meant to define. ${ }^{22}$ Spenser cannot fully resolve these questions and leaves them hanging, like so much else in The Faerie Queene, until a final reckoning that never comes. It falls to Christopher Marlowe to make the conceptual leap that Spenser resists, crafting a protean romance hero who is an enthusiastic product of will, force, and his pagan arms. Tamburlaine is a pagan knight and 'scourge of Turkes', constructed from the same heterogeneous materials as Artegall and Scanderbeg but disconnected from the Christian doctrine and nationalist history that serves to anchor the identities of those heroes. Tamburlaine is a knight of the 
second world, and a warrior who threatens to undermine the delicate English identity Spenser has crafted.

\section{'Barbary is unpeopled'}

In part two of Tamburlaine, Christopher Marlowe's Scythian conqueror, having conquered Arabia and humiliated the empires of the Persians and the Ottoman Turks in his first play, hears reports from his lieutenants Usumcasane and Techelles. Drawing on the geography of Abraham Ortellius' Teatrum Orbis Terrarum, ${ }^{23}$ the client kings describe the marshalling of their domains for Tamburlaine's continuing conquest. Usumcasane reports, 'From Azamour to Tunis near the sea / Is Barbary unpeopled for thy sake' (1.6.6-7). ${ }^{24}$ Techelles offers a 'host of Moors trained to the war, / Whose coal black faces make their foes retire / And quake for fear' (1.6.14-16) and says again that 'All Barbary is unpeopled for thy sake' (1.6.22). Thus far we are inside the bounds of the early modern world as it was understood by European geography and ethnography, but lands like Barbary have become 'unpeopled', their populations instrumentalized in an effort to make the entire world respond to Tamburaline's will. As the lieutenants begin to describe the conquests they have carried out with 'our men of Barbary' (1.6.47), the world they describe suddenly becomes a very different place. In the midst of describing his conquest of Egypt, Techelles crosses an invisible line, moving from the geographical Nile to a place

Where Amazonians met me in the field, With whom (being women) I vouchsafed a league, And with my power did march to Zanzibar.

While still within the confines of Ortellius's Africa, Techelles has marched through the blank space on the map, leaving the known world for the land of the Amazons. The Scythian Techelles, by allying with these women, reenacts Herodotus's account of the marriage of the Amazons and a Scythian tribe, after which 'the camps were combined' (IV.111-14). ${ }^{25}$ Without breaking stride, Tamburlaine's conquest of the Muslim world becomes an adventure in the lands of romance. John Gillies has highlighted the anachronism of Tamburlaine's geography, which 'invests a fifteenth-century Mongolian conqueror with a late-sixteenth-century geographic imagination', ${ }^{26}$ but the anachronism goes even deeper than that. As the conqueror and his lieutenants speak, the geography of classical antiquity suddenly springs up within Ortellius's map 
and the terrain reorders itself around Tamburlaine's will like Spenser's Faeryland.

Like Spenser, Marlowe encloses the Islamic world inside a romance space. Even as he uses the Teatrum Orbis Terrarum to plan his conquests, Marlowe places Tamburlaine in an affective space that expands and contracts with the conqueror's will. Tamburlaine 'brings a world of people to the field' (1.1.67) and deploys them at will, remaking the human products of particular histories into the commensurable instruments of his power. Within the bounds of Ortellius's atlas, Marlowe creates a romance space that bears a striking resemblance to the Faery geography described by Harry Berger:

Spenser's world and its places are not actualized in advance like an obstacle course waiting to steer its assayers toward their preordained goal. They emerge out of the problems and actions of his characters. Spenserian landscape for the most part evolves from the projection of inscape. ${ }^{27}$

While Tamburlaine's geography may seem to exist in advance of Tamburlaine, presenting conquests to come, one must remember that it is Tamburlaine himself, and later his lieutenants, who describe and call into being the lands he then conquers. This illusion of futurity in the landscape is itself a product of Tamburlaine's inscape, his ever-advancing appetites.

Like Arthur and Artegall, Tamburlaine exists in a romance space of primitive force and justice, a world without love, sustained by violence and built around his desires and actions. Like those knights, Tamburlaine defeats his foes and conquers his romance realm by appropriating pagan arms and armour, introducing himself to Zenocrate (and the audience) by trading his shepherd's weeds for 'This complete armour and curtle-axe' (1 Tamb. 1.2.41), presumably plundered from the Persians. ${ }^{28}$ Just as Arthur's shield reflects, reshapes, and destroys his foes, Tamburlaine's repetition of his enemies' rhetoric back to them and his appropriation of their powers are central to his victory. The difference between the two warrior princes arises from Marlowe's eager embrace of the commensurability that Spenser resists. While Spenser's knights are equipped with cultural constructions from across time and space, their grounding in the larger national project of the epic, and their service to Elizabeth-figures like Gloriana and Mercilla, partially anchors their identities as Christian British knights. A strong sense of national identity and a material geography underlying Faery also helps to moor their identities and actions; 'just as the multiform idea of Cleopolis [Gloriana's court] elucidates 
the quests of Guyon, Calidore, Redcrosse, and Artegall', writes Wayne Erickson, 'so the British origins of Arthur's and Britomart's quests help to define their meanings'. ${ }^{29}$

Tamburlaine, on the other hand, is unmoored from any sort of well-defined history or geography. He is 'a shepheard by [his] parentage' ( 1 Tamb. 1.2.35), placing his origins in the second world of the pastoral rather than any geographic location. In this way he more resembles a Faerie knight like Guyon or Calidore than the Saxon Redcrosse or the Briton Arthur. Like the Faerie knights, Tamburlaine, for the majority of his plays, is immune to feelings of doubt, despair, or inadequacy, although he displays a good deal more cunning and self-consciousness. Tamburlaine is a man fashioning himself into a creature of Faery, an Arthur shrugging off his confining mission to become some potent combination of Guyon, Orgoglio, and the Souldan, but with the intelligence and self-awareness to appreciate and utilize the freedom such a syncretic identity provides.

By coming from the second world, and having his adventures in a land that marginalizes Christian Europe as 'terra incognita', Tamburlaine highlights the dangers romantic syncretism poses to a stable conception of identity. Just as Arthur and Artegall risk having their British identities effaced by their pagan arms, Britain itself is largely effaced in Tamburlaine. Britain is mentioned only obliquely, during a description of how 'from the East unto the furthest West / Shall Tamburlaine extend his puissant arm' (1 Tamb. 3.3.246). After describing an empire that will stretch 'from Persepolis to Mexico' (3.3.255), Tamburlaine closes his speech by vowing to conquer 'all the ocean by the British shore. / And by this means I'll win the world at last' (3.3.259-60). Spenser used the 'Britain' he found in the chronicles to ground his poetic project in a deep and heroic national history that would unite the disparate lands and peoples of Britain and Ireland. Tamburlaine's reference to 'the British shore' instead suggests indifference, lumping England, Ireland, Scotland, and Wales together under a convenient term so he can describe the far more valuable seas they lie beside. Far from being an imperial metropolis, Britain is an insignificant fringe, an afterthought on the edge of an alien empire that barely acknowledges it, the land Pliny described as the utmost bounds of the earth ... beyond which there is nothing to be discovered but a vast prospect of air and water. ${ }^{30}$ In part this may be a negotiation of English anxieties about Ottoman power, as Tamburlaine, while remaining hostile to Islam, largely adopts the role of Ottoman Sultan after his defeat of Bajazeth. But since this is Tamburlaine's empire, the threat is not an invasion by Turkey but an 
invasion by Faery, as the romance world of pagan power that Spenser uses to construct a British identity now threatens to efface it. Just as Artegall is sent to subdue Eirena's kingdom, so too might Tamburlaine come to subdue a Britain made indistinct by its constant mimicry.

Too easily uncoupled from nationalist projects, the syncretic romance hero, in combination with his mimetic others, becomes a mighty fictional tyrant. The same cultural work that allows Arthur to defeat the Souldan also creates Tamburlaine, a tyrant more fearsome than the Souldan ever was. The alien arms that empower the English hero can be his undoing, subsuming the very self they were meant to construct.

Justin Kolb

\section{Notes}

1 Daniel J. Vitkus, Turning Turk: English Theater and the Multicultural Mediterranean, 1570-1630 (New York, 2003), 3.

2 Nabil Matar, Turks, Moors, and Englishmen in the Age of Discovery (New York, 1999), 14.

3 Chapter XI, 'Moslems on the London Stage', in Samuel Chew, The Crescent and the Rose: Islam and England During the Renaissance, 1937 (New York, 1965), 469-540, Nabil Matar, Islam in Britain, 1558-1685 (Cambridge, 1998), and Daniel J. Vitkus (ed.), Piracy, Slavery, and Redemption: Barbary Captivity Narratives from Early Modern England (New York, 2001).

4 Matar, Turks, Moors, and Englishmen, 14.

5 Benedict Robinson's Islam and Early Modern English Literature: The Politics of Romance from Spenser to Milton (New York, 2007), analyzes Book V of Spenser's Faerie Queene to argue that the images of pagan knights and the Souldan, and Arthur's donning of Pagan armour, are results of 'a crisis of representation in early modern romance' (27), resulting from the fracturing of a once united western Christendom and the formation of new 'European' identity.

6 Vitkus, Turning Turk, 8.

7 Ibid, 9.

8 Jonathan Burton, 'Anglo-Ottoman Relations and the Image of the Turk in Tamburlaine', Journal of Medieval and Early Modern Studies 30 (2000), 125-156, 126. 
9 John Foxe, Actes and Monuments of matters most speciall and memorable, happening in the Church, with an universall history of the same, 2 vols (London, 1596), 1.675.

10 All Faerie Queene citations are taken from Edmund Spenser, The Faerie Queene, ed. A.C. Hamilton (New York, 2001).

11 The History of George Castriot, Surnamed Scanderbeg, King of Albanie. Containing his famous actes, his noble deeds of Armes, and memorable victories against the Turkes, for the faith of Christ. Comprised in twelve Bookes: By Jacques de Lavardin, Lord of Plessis Bourrot, A Nobleman of France. Newly Translated out of French into English by Z. I. Gentleman (London, 1596, sTC 15318), 496.

12 Background on Scanderbeg is adapted from Chew, Crescent and Rose, 474-5 and Franz Babinger, William C. Hickman, and Ralph Manheim, Mehmed the Conqueror and His Time, $2^{\text {nd }}$ edn, ed. and trans. Ralph Manheim (Princeton, 1992), 53-6.

13 Richard Hillman, "Not Amurath an Amurath Succeeds": Playing Doubles in Shakespeare's Henriad," English Literary Renaissance 21 (1991), 168.

14 E.K. Chambers, The Elizabethan Stage, 4 vols (Oxford, 1923), 4.400. Attempts have been made to credit either Marlowe or Nashe with this play, but none are particularly convincing.

15 All citations from Spenser's shorter poems taken from Edmund Spenser, The Yale Edition of the Shorter Poems, ed. William A. Oram, Einar Bjorvanid, Ronald Bond, Thomas H. Cain, Alexander Dunlop, and Richard Schell (New Haven, 1989), 775.

16 In a less elevated encomium, Thomas Nashe's Lenten Stuff claims that a man who subsists on red herring alone for five years 'shall beget a child that will be a soldier and a commander before he hath cast his first teeth, and an Alexander, a Julius Caesar, a Scanderbeg, a Barbarossa he will prove ere he aspire to thirty'. J. B. Steane (ed.), The Unfortunate Traveller and Other Works (New York, 1985), 420.

17 Quintus Curtius, History of Alexander I, trans. John C. Rolfe (Cambridge, 1946), IV.ix.5, 244-5. The New Revised Standard Edition of The Holy Bible with Apocrypha (Oxford, 1989), 2 Macc. 13.2. See also Michael West, 'Spenser's Art of War: Chivalric Allegory, Military Technology, and the Elizabethan Mock-Heroic Sensibility', Renaissance Quarterly 41.4 (1988), 654-704, esp. 674-5.

18 While I agree with Vitkus (Turning Turk, 11) in finding rigid and limiting Edward Said's extension of orientalism to include over two thousand years of western culture — from Homer to the present — Said's at times dehistoricized reading of divisions between East and West is useful in understanding how anachronistic forms of alterity can be conflated to construct a trans-historical oriental other. It may be interesting to read Said as performing the same narrative move as that performed by Spenser in constructing the Souldan, both writers seeking to create time-transcending structures of alterity. See Edward W. Said, Orientalism (New York, 1979), esp. 49-73. 
19 Edward Kellett and Henry Byam, A Returne from Argier, A Sermon Preached at Minhead in the County of Somerset the 16 of March, 1627, at the re-admission of a relapsed Christian into our Chvrch (London, 1628).

20 Michael Taussig, Mimesis and Alterity: A Particular History of the Senses (London, 1993), 237.

21 Barabara Fuchs, Mimesis and Empire: The New World, Islam, and European Identities (Cambridge, 2001), 6.

22 This instability can be seen in later stage comedies, where Scanderbeg's name appears frequently as an epithet for rogues, bastards, and scoundrels. In Ben Jonson's Every Man in his Humour (1601), for example, Stephano angrily calls the clever servant Musco a 'Whoreson Scanderbag rogue' (1.2.21); see J. W. Lever (ed.), Every Man in His Humour: A Parallel-Text Edition of the 1601 Quarto and the 1616 Folio (Lincoln NE, 1971). Thomas Randolph's Hey for Honesty, in W. Carew Hazlitt (ed.), The Poetical and Dramatic Works, 2 vols (London, 1875), features a character boasting that he will be 'the Scanderbeg of the Company, the very Tamberlain of this ragged rout' (3.1), an example of how the names of both characters became associated with braggarts and pretensions to martial prowess. The hybridity and heroic self-fashioning that Spenser celebrates in his dedication to Scanderbeg and which Marlowe appropriates for Tamburlaine are comically refigured as rootless cunning, dissimulation, pretense, and roguery.

23 Ethel Seaton, 'Marlowe's Map', Essays and Studies by Members of the English Association 10 (1924), 13-35.

24 All Tamburlaine citations taken from Christopher Marlowe, Tamburlaine: Parts one and two, ed. Anthony B. Dawson (New York, 1997).

25 Herodotus, The History, trans. David Grene (Chicago, 1987), 320-1.

26 John Gillies, 'Tamburlaine and Renaissance Geography', in Garret A. Sullivan Jr., Patrick Cheney, and Andrew Hadfield (eds), Early Modern English Drama: A Critical Companion (Oxford, 2006), 37.

27 Harry Berger Jr, Revisionary Play: Studies in the Spenserian Dynamics (Berkeley, 2005), 23.

28 Modern editions of Tamburlaine usually insert a stage direction here of Tamburlaine pulling off his shepherd's clothes to reveal armour underneath, like Clark Kent transforming into Superman. I believe it would be better to have Tamburlaine's bandits take pieces of armour out of their chests of plunder and dress him in them as he speaks, emphasizing his appropriation of foreign arms as part of his self-fashioning.

29 Wayne Erickson, Mapping the Faerie Queene: Quest Structures and the World of the Poem (New York, 1996), 100. 
30 Pliny, The History of the World, Commonly Called the Natural History of C. Plinius Secundus, or Pliny, Translated by Philemon Holland, ed. Paul Turner (New York, 1964), 312-13. While more concerned with the Americas than Asia and the Mediterranean, Jeffrey Knapp's An Empire Nowhere: England, America, and Literature from Utopia to The Tempest (Berkeley, 1992) analyzes the centrality of England's remoteness and detachment to the geographic invention of early modern writers, in whose hands 'England's otherness could, then, be construed either as barbarous or as heavenly' (65). See also John Gilles, Shakespeare and the Geography of Difference (Cambridge, 1994), 31.

\section{Guy of Warwick, Godfrey of Bouillon, and Elizabethan Repertory}

Marlowe's Tamburlaine had a pervasive influence on the early modern stage and in particular on those plays grouped under the flexible generic label 'Turk plays'. This influence has been discussed at length, and discussion frequently focuses upon core texts, including early examples such as Robert Greene's Selimus and Alphonsus, King of Aragon, Peele's The Battle of Alcazar, Kyd's Soliman and Perseda, and later examples such as Shakespeare's Othello, Robert Daborne's A Christian Turn'd Turk, and Massinger's The Renegado. ${ }^{1}$ In this essay, however, I discuss the anonymous play The Tragical History, Admirable Atchievments and various events of Guy earl of Warwick and Thomas Heywood's The Four Prentices of London. These two plays can also be situated within the parameters of 'Turk plays' but have received much less critical attention in this context. Part of the reason for this neglect is that the dates and performance histories for both plays are sketchy or nonexistent. The dates of publication for both plays are not contemporaneous with the dates for their initial performances in the theatre: while The Tragical History was published in 1661 and The Four Prentices in 1615, critics have suggested that both plays are Elizabethan and were written for performance during the 1590 s. $^{2}$ Part of the support for such dating of the plays stems from the traces of Marlovian influence apparent in both, not only regarding verse style and interest in stage spectacle, but also in the ways both plays draw on the theatre's interest in and depiction of Islamic powers, either Turkish or Persian. To capitalize on the success of Marlowe's play and others like it, dramatists such as Heywood and the author of The Tragical History turned to medieval history and romance narratives for heroes whose stories they could dramatize. The 